\title{
Using Online Short Stories to Improve the Reading Comprehension Ability
}

\author{
Muhammad Lukman Syafi \\ Muhammadiyah University of Ponorogo \\ s.muhammadlukman@yahoo.com \\ DOI : http://dx.doi.org/10.18326/rgt.v11i2.168-191
}

\begin{abstract}
Submission
Track:

ABSTRACT

Received:

$11 / 08 / 2018$

Reading materials can be obtained from many sources, like storybooks,

Final Revision: magazines, and the Internet. Online Short Stories is one of the Internet resources which are completed with images and sound and quizzes. This study was aimed at benefiting these readily used materials to

$25 / 11 / 2018$ improve the eighth graders' reading comprehension of narrative texts. The Online Short Stories are combined with five worksheets that

Available online: consist of guiding questions on comprehension, namely: Self Monitoring Card, Key Concept, Story Map, Reading Journal, and $01 / 12 / 2018$ Reading Log which are used for intensive and extensive reading activity. This study implemented classroom action research design and took 34 eighth graders of MTs Al-Islam Joresan Mlarak Ponorogo 2017/2018 academic year as the subjects. Based on the results of the students' tests as well as their on-going assessments, it is found out that the students' reading comprehension was gradually improving. It means that there was a positive effect of using Online Short Stories towards the students' reading ability. The result shows that the combination of materials and worksheets that were implemented in both cooperative and individual learning had facilitated the students in improving their reading comprehension ability, as well as their social skills. Therefore, it is very important to implement this strategy to order to improve the students' reading comprehension.
\end{abstract}

Keywords: Online Short Stories, Improvement, Reading Comprehension Ability

\section{INTRODUCTION}

Reading is one of four English language skills that a student has to master as the main goal of learning English besides listening, speaking, and writing. It is also established in Junior High School on the basis of School-Based Curriculum (Kurikulum Tingkat Satuan Pendidikan), in which students are guided to develop their language skills for both oral and 
written communication in daily context (Depdiknas, 2006). Dealing with this goal, SchoolBased Curriculum has offered great chances for every school and teachers to design their own syllabus based on students' input, materials on syllabus connected with environment needs, and school facilities.

Although reading is a receptive skill, as listening, it involves active learning processes in which students incidentally learn the familiar and difficult words, so that they can understand through the contextual support from the text. It concerns with an effort to understand and interpret the meaning of the writing products to learn new concepts about the world. Nuttall (1982) states that this skill does not cover decoding and pronouncing, but it needs comprehending. Thus, later on, when students have mastered reading as one of four language skills, later they will easily master the other three skills, namely, listening, speaking and writing. Therefore, reading activities should be modified to be enjoyable to get students' input increases.

Reading and writing are of students' routines at school that facilitates them to learn school subjects, in fact, our national reading habit index remains low. This is supported by the data from the World Bank showing that Indonesian students rank is the lowest in reading habits among their peers in Southeast Asia. The score is 51.7. Singapore has a score of 74.4, Thailand is 65.1 and the Philippines' score is slightly higher at 52.6. Hong Kong, by contrast, has a score of 75.5 (Atmadja, 2010). This is mainly influenced by the socio-cultural value in which Indonesia has "speech habit" not "reading habit". In order to bring the students having a reading habit, basically, formal environments have had great efforts to encourage students' motivation, intrinsically and extrinsically, especially for reading English texts.

In addition, the similar of the alphabetical system does not support much that reading in English is not sophisticated. The great differences in letter-sound bring the effect on the difficulty of pronouncing and remembering a lot of vocabulary. This becomes one of the reasons why students are less interested in English. Another reason is that many schools, particularly in rural area, are lack of English reading materials. Ideally, fulfilling the materials should be fitted to the students' needs. These are the common problems occurred in some primary schools, both Junior and Senior High Schools, either at the urban or rural area in Indonesia.

Dealing with those problems, especially in reading, teachers prefer applying various teaching techniques along with the use of interesting materials and media. The researcher 
used Online Short Stories as the best solution that is chosen on the basis of some reasons, mainly to take benefit of the facilities that have already provided by the school as a research setting. Firstly, Online Short Stories present some features that support students' reading activity. They are readily used materials that are taken from the Internet. They can be benefited from learning media and resources. Pictures or animations help readers catch the meaning of sentences that appear by pages. Oral reading helps the students maintain their pronunciation. Reading exercises and games in the form of vocabulary and comprehension quizzes facilitate students to understand the content of the text. So far, they can do selfcorrection. In addition, students can encourage their thinking while they are reading. In line with this, Neyman (2002) adds that the treatment of pronunciation correction to the students while reading aloud and simple explanation when students come to different tenses in the stories increases students' willingness and ability to use the words they have mastered from the stories. Secondly, Online Short Stories are updated regularly by the authors (providers), such as British Council Learn English Kids, Rong Chang ESL, Magic Keys, and Oxford University Press. Thirdly, these free and inexpensive sites present various materials and topics which vary in terms of readers' age, difficulty levels, and the length of the stories. Fourthly, the choice of the Internet as a learning medium and source is because of its advantages in terms of interactivity matter. In this case, the teacher is required as the main holder that creates an effective interaction between students, teacher, and material through computer even the Internet as media (Harmer, 2007). Fifthly, the use of this media helps teachers to solve the problems of access and expense. Teachers are possible to find other sites which provide materials that are downloadable and photocopiable for students' use if the school has limited facilities for internet access (Mikulecky, 2007).

Online Short Stories is worthy Internet resources since it provides an alternative for the schools that have a limitation on providing students with adequate English materials but has high accessibility on the Internet. The researcher decides to use these Internet resources online rather than offline because the appearances are more interesting. Besides, it is also to benefit the computer laboratory that provides free Internet access and adequate spaces for a class to have activity there. These materials can also be developed into booklet form. However, more expense would be needed for the publication process, and more time would be demanded arrangement process. 
Considering that, Online Short Stories are as alternative materials for teaching reading, the researcher focuses on teaching narrative texts. A narrative tells a story in a chronological order and entertains readers (audience). It provides a lesson and a plot, which allows readers' emotion to come into the story. Through narratives, students are expected to be able to learn the language at ease. They will be encouraged to understand the story chronologically (Anderson \& Anderson, 1998). Here, teachers can apply story structure or graphic organizers in whilst or post-reading activities -during or after online reading- to help students specify the parts of the story and make them related to each other. Students' understanding of narrative centers -setting, characters, plot, and theme- enhance them to create a coherent framework for understanding and remembering the text. At last, students will also encourage their comprehension of explicit and implicit elements of the story, and the generic structure used by the author in the text (Vacca \& Vacca, 1999).

Due to the problem above, the researcher also proposes an implementation monitored extensive reading as extra-class work. It is a sort of reading activities conducted out of the classroom as homework. Here, the teachers give a longer time to finish and do monitoring to know the students' work. This may be considered as an alternative solution for time allotment, specifically in giving well balanced on four language skills. The characteristics of this program are evident the provision of a large number of reading materials in various topics and genres, supplement longer time-out of the classroom, encouragement by teacher's modeling, free of choice based on students' interest, need, ability, and give post-reading activities (Renandya \& Jacobs, 2002). So far, the application of extensive reading enhances students learning to increase their knowledge and understand their personal needs. Moreover, reading habit will be gradually developed along with the students' joyful learning and improved reading.

Along with multimedia progressing in education, web-based extensive reading (Web-ER) program helps students learn vocabulary, read for main ideas, and acquire speed and/or fluency in reading a text. Besides, Silva (2006) finds that Web-ER becomes interesting method though some of the students get their doubt. However, it shows that a transition period is needed by the students to make the necessary adjustments in formulating their habits. It seems that over time, students may develop positive attitudes towards reading online and Web-ER. Meanwhile, the bad effect shows that online education makes an isolation of students from the teachers. 
There are some previous studies which focus on multimedia usage. The use of multimedia in writing has shown a significantly positive effect on students' achievement. The students' writing ability is improved by using multimedia compared to nonmultimedia. The implementation of multimedia can lead students to the positive attitudes in valuing English learning and increase their motivation (Khamim, 2009). Another study discusses the use of multimedia CD-ROM as delivery media, which contained courseware for incidental vocabulary learning and implicitly vocabulary learning. This encourages the students to be more responsible toward their learning (Effendi, 2005). Dealing with extra-class work, a study has been conducted on Intensive Extensive Reading Activity (INEXRA) by Argarini (2008). This activity applied six aspects of reading: motivation and development of background, directed reading, skill building, follow up activities, at home activities, and enrichment. However, the significant result has been shown on three out of six aspects. The students are encouraged on their motivation on the development of background knowledge, skill building and follow up activities.

Dealing with the need of implementing Online Short Stories as a medium and materials for teaching reading on narrative texts, the research problem was formulated as follows: How can the use of Online Short Stories improve the reading comprehension ability of the eighth graders at MTs Al-Islam Joresan Mlarak Ponorogo? However, this study focuses on implementing Online Short Stories which are from the Internet as a medium and materials that are combined with a worksheet and collaborative learning.

\section{RESEARCH METHODS}

In this study, the researcher applied action research design since it opens the opportunity for teachers-practitioners to be involved in research. The Kemmis and McTaggart's (1988) design of classroom action research is a form of 'self-reflective inquiry' in which teachers are supposed to improve and judge their practice as well as knowing the problems arise and finding for the solution. The 'classroom research by teachers' lead to produce an alternative model or method and teaching procedure as well that enhance meaningful interaction between teachers-students and among students and result on effective learning (Hopkins, 2008). 
The study took one subject class of the eighth grade of MTs Al-Islam Joresan Mlarak Ponorogo that consists of 34 students. The subjects were chosen under the consideration that most of them got scores lower than minimum passing criteria, 60, in a reading test delivered in a preliminary study. The researcher needed two English teachers as a collaborator who observed the implementation of Online Short Stories as medium and materials for reading and the effect on the students' learning and achievement. The results of observation became research findings that included the students' involvement in the teaching and learning process, and their achievements. They were analyzed quantitatively and then described qualitatively.

\section{Planning the Action}

In the planning phase, the researcher designed a lesson plan as the basic point of the action that comprised the teaching strategy. Here, the researcher planned an action with four meetings for one cycle within a consideration that the students need to learn the way to interact with online texts and use some worksheets to help them comprehend the meaning of the text in both intensive and extensive reading activities.

The strategy employed in this study was Online Short Stories (OSS). The role of OSS as a strategy was under the reason that strategy can be any kind of tools or ways that a teacher uses to help learners learn (Tyner \& Green, 2005). Online Short Stories were ready used materials for reading comprehension that were taken from the Internet. There were two sites that were chosen for this study, the British Council and Rong Chang (2010). They present many narratives on numerous topics. British Council site offers several kinds of narratives such as fable, folk tales, adventure, fantasy, and science fiction. They are appropriate reading materials for eighth graders since the themes are apt and attractive for teenagers. Besides, each story provides an oral reading which helps students maintain their reading pronunciation. Rong Cang site is quite the same. On the contrary, there are some features of reading comprehension exercise, list of vocabulary, and puzzle for each text. These features provide students some instrument for self-improvement in their reading skill. Furthermore, these media and materials cover the diversity of students' learning style, and meet the provision of constructivism where students are allowed to maintain their roles to construct their knowledge by interacting with their environment; computer, worksheet, and teachers and friends (Gardner, 1983; Goose, Gunn \& Swinkles, 2002 cited in Mohtar \& Saad, 2007; Richards \& Rodgers, 2001). 
Online Short Stories were not the sole device used in this study although they were the main sources of narrative texts for a reading activity. The researcher combined with some worksheets which were used for groups, pairs, and individual work during the teaching and learning activities. The first two worksheets were self-monitoring card and key concept adapted from Jitendra et al (2000 cited in Klingner, 2007) for whilst reading activity. The selfmonitoring card has a similar function to The Five Ws graphic organizer proposed by McKnight (2010) for fiction text in which the questions are used o lead the students to get the core on the text. These instruments are prepared to help the students to make some notes on the worksheet based on the focus given in the form of questions. The third worksheet was a story map. That is used for the post-reading activity. This facilitates the students with a map or graphic so that they can draw their concept on the narrative text being read so that they would be familiar with its rhetorical structure. The collaborative strategic reading which entails story map or graphic organizer, which are rooted from story grammar, will enable students to derive coherent framework of the story so that they understand and remember the text (Vacca \& Vacca, 1999).

Other reading worksheets used were reading the journal and reading the log. The reading journal was adapted from J. Eury's (1994 cited in O’Malley and Pierce, 1996) model. It is used to lead the students to write any responses or comments towards narratives they have read. Then, they could record all narratives in the reading logs. These two instruments were used in both intensive and extensive reading activities. The difference was that students submitted their report books that consisted of reading the journal and reading log weekly. This combination of the strategy was implemented in the three-phase technique of reading; Prereading, Whilst-reading, and Post-reading.

\section{Implementing the Action}

In the implementation stage, the researcher performed as a teacher who carried out the teaching of reading comprehension based on the teaching strategy and lesson plan. The collaborators acted as observers who kept noticing on the process and took some important notes. The teaching procedures are presented in table 1.

Table 1 Teaching Procedures

Stage Teacher's activities




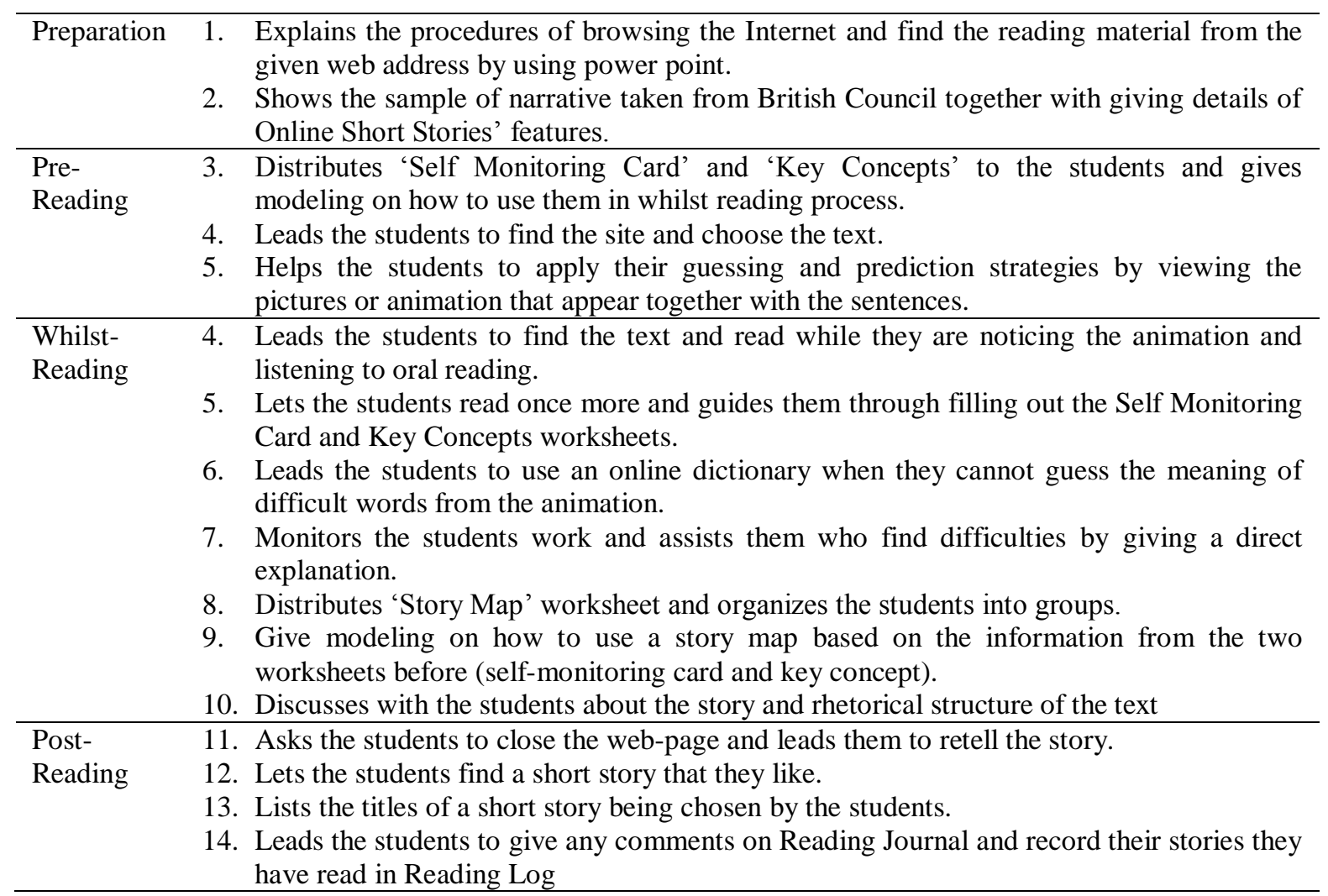

The differences in implementation in Cycle 1 and cycle 2 are that the numbers of meetings and the group working that was employed. Number Heads Together was undertaken because most of the students were choosy in the grouping. It meant that each student has great opportunities to work with whoever their friends in the classroom so that they can also improve their social skills. Table 2 described the schedule of the implementation of both intensive and extensive reading.

Table 2 Schedule of the Implementation

\begin{tabular}{|c|c|c|c|c|}
\hline Date & Intensive Reading & Materials & $\begin{array}{c}\text { Extensive } \\
\text { Reading }\end{array}$ & Deadline \\
\hline Jan 26 & $\begin{array}{l}\text { Introduction and teacher's } \\
\text { modeling on reading online in } \\
\text { groups by utilizing worksheets } 1 \text {, } \\
2 \text {, and } 3 \text {, and grouping. }\end{array}$ & The Lucky Seed & & \\
\hline Feb 2 & $\begin{array}{l}\text { Reading online in pairs by utilizing } \\
\text { three main worksheets }\end{array}$ & Free choice & & \\
\hline Feb 9 & $\begin{array}{l}\text { Reading online individually and } \\
\text { filling in a reading the journal and } \\
\text { reading the log. }\end{array}$ & Eric the Engine & 1 & Feb 8 \\
\hline Feb 23 & $\begin{array}{l}\text { Reading online other freely chosen } \\
\text { texts, and filling out the simplified } \\
\text { worksheets. }\end{array}$ & $\begin{array}{l}\text { Dinosaur Dig, } \\
\text { Monster Shopping } \\
\text { Trip }\end{array}$ & 2 & Feb 15 \\
\hline Mar 4 & Reading Comprehension test 1 & & 3 & Mar 1 \\
\hline Mar 13 & $\begin{array}{l}\text { Reading online in groups by } \\
\text { Number Heads Together, then }\end{array}$ & $\begin{array}{l}\text { The Hungry } \\
\text { Dragon, Little }\end{array}$ & 4 & Mar 8 \\
\hline
\end{tabular}




\begin{tabular}{|c|c|c|c|c|}
\hline & $\begin{array}{l}\text { working individually within } \\
\text { limited time on modified } \\
\text { worksheets }\end{array}$ & Red Riding Hood & & \\
\hline Mar 15 & $\begin{array}{l}\text { Reading other freely chosen texts } \\
\text { individually and working on the } \\
\text { same worksheets }\end{array}$ & The Magic Spell & 5 & Mar 15 \\
\hline Mar 25 & Reading Comprehension test 2 & & & \\
\hline
\end{tabular}

\section{Observing and Collecting Data}

The observation was aimed at gathering data related to the implementation of the strategy. Both quantitative and qualitative data are gathered from the subjects of the study, the eighth graders of MTs Al-Islam Joresan Mlarak Ponorogo. The numeric data on the students' score on reading comprehension was obtained from students' achievement through reading assessment whilst and after the strategy implementation as the main data. This showed whether or not the strategy improves the students' comprehension. Meanwhile, the descriptive data were collected using an observation checklist, field notes, and questionnaires that gave information on the implementation of online reading from Online Short Stories for intensive and extensive reading.

The researcher used four kinds of instruments. Firstly, reading tests were used to know students' ability after the implementation of the strategy. These were delivered to assess their achievement at the end of the cycle. Each test consisted of 15 items that asked general and specific information of the text, including story centers. The first reading test was quite similar to the second one. They were different in the texts used and the form. Two narrative texts for reading comprehension test Cycle 1were adopted from the stories in British Council which were taken randomly. Two narratives for reading test in Cycle 2 were adopted from Starfall ESL reading in Rong-Chang site and www.semrock.com, and another text was adapted from www.eastoftheweb.com. However, the score that decided a student's progress on his/her learning was not counted from the reading test only. Other instruments used in the on-going assessment were students' worksheets; self-monitoring card, key concepts, and story map which were completed with scoring rubrics. Then, the reading journal and reading log made in the booklet were also analyzed in order to get additional information on the students' extensive reading.

Secondly, two kinds of questionnaires were delivered after the implementation in the forms of close-ended questions. The first questionnaire was intended to know the students' 
responses towards the implementation of the strategy and students' enthusiasm. It consisted of ten questions in which the students were required to answer them openly through the two options given, agree or disagree. The second questionnaire elaborated three options; good, poor, and bad, through which the students could express their contentedness with the researcher's way of applying the strategy.

Thirdly, observation checklists were used to gather information concerning with students and teacher's performance during teaching and learning process in the classroom. The checklist that was prepared was utilized totally the students' involvement up in teaching and learning process. This was simplified so as the second observer could use the presence list to eye all the students' movement and record their participation. From this form, both the researcher and the second observer as the English teacher in that class could reveal the result on the strategy on their partaking. The indicators included in the checklist represented the students' responses towards the use of the strategy, such as responding to the teacher's instructions, asking for help or explanation, answering teacher's questions during the discussion, having great willingness in retelling story and finishing the works assigned.

And the fourth was field notes utilized to record other brief and important information about the teacher's performance in implementing the strategy and the students' responses that observers had seen and heard but exclude in observation checklist.

\section{Reflecting}

The researcher went to this last step to interpret the information gathered during the implementation phase. The findings were analyzed, so, the researcher would know whether the implementation had reached the criteria of success or not. Thus, the implementation of Online Short Stories would be successful if the criteria of success were achieved. That was all the students in the classroom achieved at least 65 in both on-going assessment and reading comprehension test. Since the study involved extensive reading (ER), this criterion was applied also for this task, that all students were expected to perform their responsibilities on extensive reading tasks which can be seen from their extensive reading record, consisting reading logs and reading journals, that were submitted in due time. In short, if students' achievement had been achieved yet, there would be a revising plan for the next cycle. However, when the result of the study that was analyzed had achieved the criteria of success, the study would be stopped and another cycle was not needed. 


\section{RESULTS AND DISCUSSION}

The findings of the study were analyzed I order to answer the research question that was obtained from observation checklists, field notes, reading comprehension test and questionnaire. The data revealed in observation checklists, field notes and questionnaire show the teaching and learning process in terms of interaction between teacher and students and among students. The data on the students' achievements were generated from the scores they got both in daily exercise and the reading comprehension test as it was shown in the following.

Table 3 Students' Participation in the Teaching and Learning Process Cycles

\begin{tabular}{|c|l|c|c|c|c|c|c|}
\hline \multirow{2}{*}{ No } & \multicolumn{1}{|c|}{ Indicators } & \multicolumn{3}{c|}{ Cycle 1 } & \multicolumn{2}{c|}{ Cycle 2 } \\
\cline { 3 - 8 } & & $\begin{array}{l}\text { M } \\
\mathbf{1}\end{array}$ & $\begin{array}{l}\mathbf{M} \\
\mathbf{2}\end{array}$ & $\begin{array}{l}\mathbf{M} \\
\mathbf{3}\end{array}$ & $\begin{array}{l}\mathbf{M} \\
\mathbf{4}\end{array}$ & $\begin{array}{l}\mathbf{M} \\
\mathbf{1}\end{array}$ & $\begin{array}{l}\mathbf{M} \\
\mathbf{2}\end{array}$ \\
\hline 2 & $\begin{array}{l}\text { Give comments or responses to the } \\
\text { teacher's instruction and questions }\end{array}$ & 8 & 11 & 18 & 18 & 21 & 18 \\
\hline 3 & $\begin{array}{l}\text { Ask for help when they get some } \\
\text { difficulties on browsing. }\end{array}$ & 0 & 16 & 13 & 5 & 11 & 5 \\
\hline 4 & $\begin{array}{l}\text { Ask for explanation on the worksheets } \\
\text { another page to find the meaning when } \\
\text { they cannot guess the meaning of } \\
\text { difficult words. }\end{array}$ & 9 & 16 & 13 & 16 & 18 & 11 \\
\hline 5 & $\begin{array}{l}\text { Have a great willingness to work on the } \\
\text { worksheets at a given time both in a } \\
\text { group or individually. }\end{array}$ & 17 & 18 & 17 & 23 & 22 & 23 \\
\hline 6 & $\begin{array}{l}\text { Give any responses while discussing the } \\
\text { story together by using worksheets 1 and } \\
\text { 2. }\end{array}$ & 10 & 11 & 12 & 19 & $*$ & $*$ \\
\hline 7 & $\begin{array}{l}\text { Give comments while discussing the } \\
\text { story map. }\end{array}$ & 4 & 7 & 11 & 14 & 11 & 14 \\
\hline 8 & $\begin{array}{l}\text { Have a great willingness to retell the } \\
\text { story. }\end{array}$ & 1 & 2 & 5 & 7 & 5 & 9 \\
\hline 9 & $\begin{array}{l}\text { Finish their work quickly before the time } \\
\text { is up. }\end{array}$ & 0 & 8 & 8 & 10 & 17 & 19 \\
\hline
\end{tabular}


Based on the results of the students' tests as well as their on-going assessments, it is found out that the students' reading comprehension was gradually improving. It means that there was a positive effect of using Online Short Stories towards the students' reading ability. The use of Online Short Stories as medium and materials for reading, especially narrative texts, could motivate them to learn and interact with the texts. The reasons were that they could learn in a different atmosphere where they could interact with the Internet individually, and they could train and improve their ability in guessing or predicting in order to understand the text. Since the students were teenagers, they enthusiastically explored the website that provides them narratives with the animation and audio support as well as exercise and games. Thus, when they got the high motivation to learn, steadily they could gain good score as it aroused from their independent training to work with texts as it was shown in the following.

Table 4 Students' Responses toward the Use of Online Short Stories

\begin{tabular}{|c|c|c|c|}
\hline No & Statements & Agree & Disagree \\
\hline 1 & $\begin{array}{l}\text { I am motivated to learn English more after learning the } \\
\text { narrative through online short stories }\end{array}$ & 33 & 1 \\
\hline 2 & $\begin{array}{l}\text { I can understand the way to find the main idea and } \\
\text { specific information from the text by using } 5 \mathrm{~W}+\mathrm{H} \\
\text { question in self-monitoring card and key concept } \\
\text { worksheets }\end{array}$ & 31 & 3 \\
\hline 3 & $\begin{array}{l}\text { Learning through Online Short Stories lets me free to } \\
\text { choose the story from the easiest to the difficult ones }\end{array}$ & 32 & 2 \\
\hline 4 & $\begin{array}{l}\text { I become more confident to follow the learning } \\
\text { activities that I can read the story I like }\end{array}$ & 16 & 18 \\
\hline 5 & $\begin{array}{l}\text { I can improve my comprehension through sharing and } \\
\text { discussion }\end{array}$ & 30 & 4 \\
\hline 6 & $\begin{array}{l}\text { I am motivated to learn and do exercise by using the } \\
\text { worksheet given }\end{array}$ & 19 & 15 \\
\hline 7 & $\begin{array}{l}\text { The using Online Short Stories help me improve my } \\
\text { knowledge on utilizing the Internet for learning }\end{array}$ & 34 & 0 \\
\hline 8 & $\begin{array}{l}\text { Online Short Stories and reading strategies, I still need } \\
\text { to improve my reading ability }\end{array}$ & 26 & 8 \\
\hline 9 & $\begin{array}{l}\text { The use of Online Short Stories creates a joyful learning } \\
\text { atmosphere }\end{array}$ & 34 & 0 \\
\hline 10 & $\begin{array}{l}\text { Online Short Stories did less support the English } \\
\text { learning process }\end{array}$ & 0 & 34 \\
\hline
\end{tabular}

The progress was shown in the students' scores from the beginning to the end of Cycle 1 and Cycle 2. Although the number of students who achieved the minimum score 
fluctuated each meeting as well as the mean score, the slight improvement in daily assignment proved the result of their hard work. In the preliminary reading test, there were 13 out of 34 students who achieved 60, minimum passing criteria in the school. Then, in the reading test Cycle 1, there were 31 students who gained at least 65, and 32 students in Cycle 2. For more detail description and comparison, Figure 1 shows the improvement of the students' mean score in on-going assessment and reading comprehension test as well as the number of students who reached 65 in Cycle 1 and Cycle 2 compared to a preliminary study.

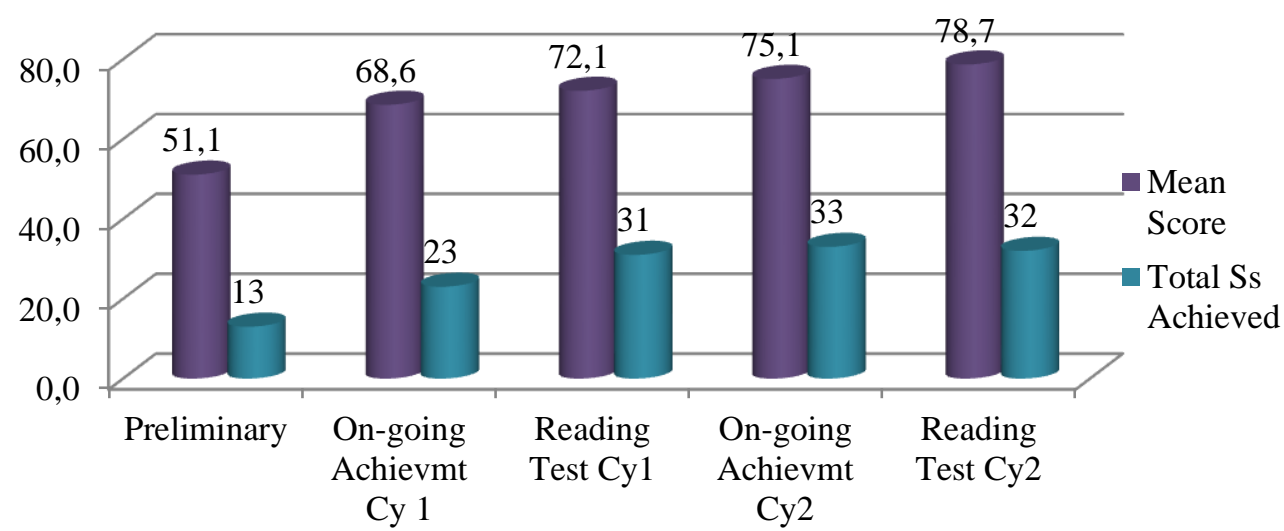

Figure 1 Mean Scores in Cycle 1 and cycle 2 Compared to Preliminary Study

In terms of participation in the teaching and learning process, the students showed their great interest to be active, although they were forced to give comments by answering teacher's questions about the text. In this case, concerning with browsing procedures and utilizing worksheet, the number of students who asked for help reduced gradually. The steady increase also happened to those who liked to respond while discussing the story together or finishing their work on time. On the other case, only a few of students showed their great willingness to retell the story till the end of meetings. Figure 2 presents the percentage of their involvement. 


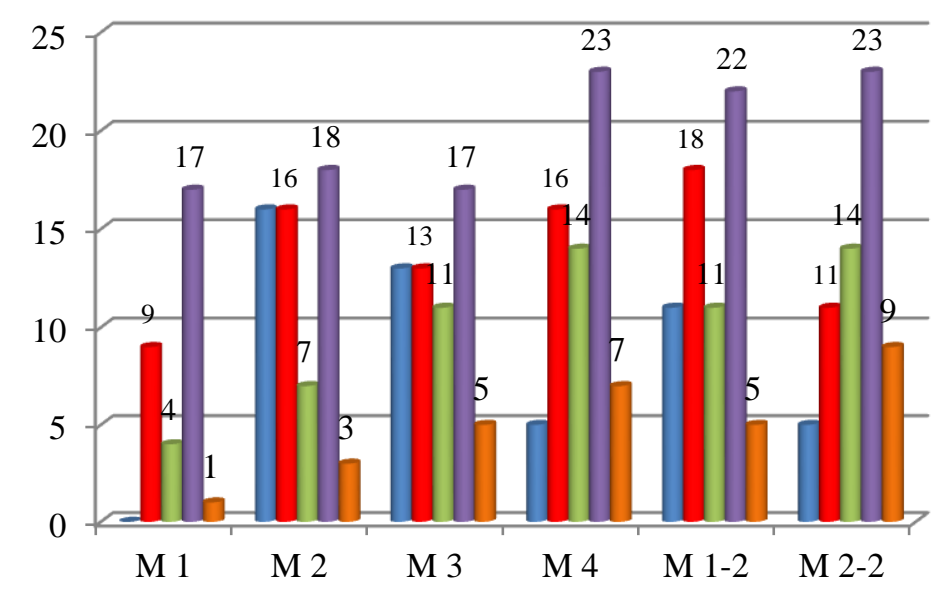

- Browsing help

- Worksheet Problem

- Responses in discussion

- Finishing works on time

- Retelling story

M 1= Meeting 1

M 1-2= Meeting 1 Cycle

Figure 2 Total Students who actively Involved in the Teaching and Learning Process

Furthermore, the result of the extensive reading task that was considered on the basis of students' accountability showed that their responses grew in line with their need for a score. This might become important findings that extensive reading needs great support in terms of time, materials, guidance, and modeling. Those would be prerequisite of how to run the course well. As being practiced in this research, the students were delighted if the school allows them to utilize the computer laboratory for learning. That was the reason why the researcher then let the students finish their work in the computer lab only for a day a week. In this case, providing the facilities became the main focus since the motivation and responsibility were the essential factors that influenced their learning as well as their achievement. Figure 3 illustrates the improvement of the students' responsibility in the period of time given. Thus, it can be concluded that in order to embrace students' interest, especially in reading out of the classroom, a series of steady steps must be the first consideration to deal with the teenage world. 


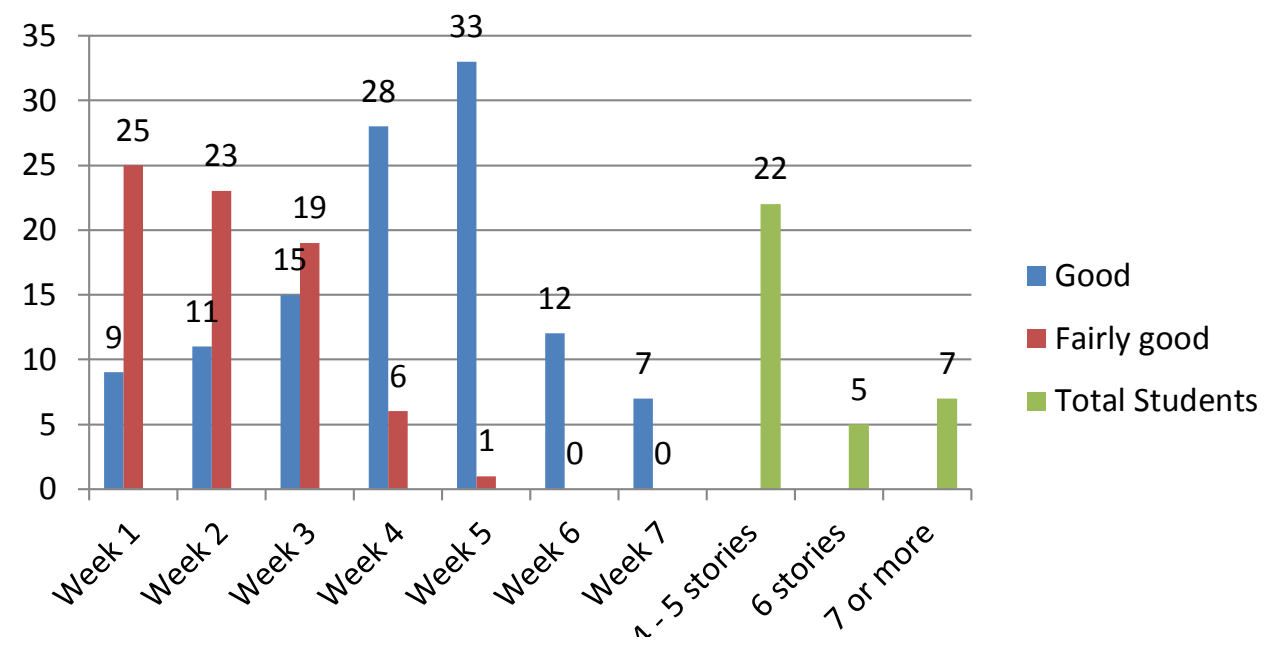

Figure 3 Students' Responsibility on Extensive Reading during Five

Weeks of Assignments

From the overall description on the students' involvement, the responses, and the achievement, the result of the implementation of Online Short Stories combined with grouping technique of Number Heads Together in Cycle 2 was better than that in Cycle 1. Although the result showed that 32 students (94\%) in the class achieved minimum passing criteria, 65 points, another cycle was not needed. The strategy was effective in triggering the students to be actively involved in the learning process as it improved their reading comprehension. However, an analysis of the students' answers on the test items was done. The result showed that there were many students who gave the wrong option in four items which three of them were inferential questions and one vocabulary meaning. In this case, the students' failure in answering test items did not lead to the conclusion that they failed because of the test only. Here were the tables related to students' final scores in cycle 1 and 2.

Table 5 Students' Scores during Learning Activities and Reading Test in Cycle 1

\begin{tabular}{|c|c|c|c|c|c|c|c|c|c|c|c|c|}
\hline No & Name & $\begin{array}{c}\text { exc } \\
1\end{array}$ & $\begin{array}{c}\text { exc } \\
2\end{array}$ & $\begin{array}{c}\text { exc } \\
3\end{array}$ & exc 4 & a-b) & ave & $\begin{array}{c}\text { ER } \\
\text { task }\end{array}$ & $\begin{array}{l}\text { Final } \\
\text { Score }\end{array}$ & note & Test & note \\
\hline 1 & AS & 81 & 60 & & 64 & 61 & 67 & 70 & 67 & achieved & 68.8 & achieved \\
\hline 2 & AN & 62 & 45 & 25 & 71 & 89 & 58 & 70 & 61 & remedial & 72.5 & achieved \\
\hline 3 & $\mathrm{AB}$ & 62 & 45 & 80 & 79 & 89 & 71 & 70 & 71 & achieved & 72.5 & achieved \\
\hline 4 & $\mathrm{AD}$ & 86 & 65 & 75 & 79 & 61 & 73 & 73 & 73 & achieved & 72.5 & achieved \\
\hline 5 & $\mathrm{AF}$ & 81 & 45 & 0 & 71 & 89 & 57 & 68 & 59 & remedial & 65.0 & achieved \\
\hline 6 & $\mathrm{AH}$ & 86 & 60 & 20 & 71 & 67 & 61 & 68 & 62 & remedial & 78.8 & achieved \\
\hline 7 & $\mathrm{AM}$ & 86 & 45 & 0 & 86 & 61 & 56 & 72 & 59 & remedial & 68.8 & achieved \\
\hline
\end{tabular}




\begin{tabular}{|c|c|c|c|c|c|c|c|c|c|c|c|c|}
\hline 8 & Anw & 86 & 60 & 45 & 71 & 72 & 67 & 70 & 67 & achieved & 72.5 & achieved \\
\hline 9 & AR & 86 & 60 & 80 & 79 & 61 & 73 & 72 & 73 & achieved & 68.8 & achieved \\
\hline 10 & AYF & 90 & 65 & 20 & 79 & 89 & 69 & 70 & 69 & achieved & 72.5 & achieved \\
\hline 11 & AMA & 62 & 60 & 0 & 64 & 61 & 49 & 70 & 54 & remedial & 78.8 & achieved \\
\hline 12 & AA & 86 & 60 & 85 & 79 & 72 & 76 & 72 & 75 & achieved & 72.5 & achieved \\
\hline 13 & Dn & 86 & 55 & 85 & 79 & 72 & 75 & 70 & 74 & achieved & 68.8 & achieved \\
\hline 14 & DC & 81 & 75 & 95 & 86 & 78 & 83 & 80 & 82 & achieved & 92.5 & achieved \\
\hline 15 & $\mathrm{AQF}$ & 81 & 75 & 90 & 71 & 67 & 77 & 73 & 76 & achieved & 65.0 & achieved \\
\hline 16 & EA & 90 & 60 & 85 & 64 & 61 & 72 & 70 & 72 & achieved & 78.8 & achieved \\
\hline 17 & EW & & 55 & 60 & 71 & 56 & 60 & 73 & 63 & remedial & 75.0 & achieved \\
\hline 18 & ETJ & 62 & 70 & 25 & 64 & 56 & 55 & 72 & 59 & remedial & 72.5 & achieved \\
\hline 19 & IY & 90 & 55 & 85 & 64 & 61 & 71 & 70 & 71 & achieved & 65.0 & achieved \\
\hline 20 & IP & 62 & 60 & 45 & 71 & 56 & 59 & 70 & 61 & remedial & 75.0 & achieved \\
\hline 21 & $\mathrm{JH}$ & 67 & 70 & 70 & 64 & 72 & 69 & 72 & 69 & achieved & 68.8 & achieved \\
\hline 22 & JP & 86 & 60 & 45 & 86 & 72 & 70 & 78 & 71 & achieved & 86.3 & achieved \\
\hline 23 & $\mathrm{MZ}$ & 67 & 75 & 25 & 79 & 56 & 60 & 72 & 62 & remedial & 72.5 & achieved \\
\hline 24 & MK & 86 & 65 & 85 & 86 & 56 & 75 & 73 & 75 & achieved & 72.5 & achieved \\
\hline 25 & $\mathrm{Nd}$ & & 80 & 80 & 86 & 72 & 79 & 78 & 79 & achieved & 60.0 & fail \\
\hline 26 & NS & 86 & 60 & 85 & 71 & 56 & 72 & 72 & 72 & achieved & 72.5 & achieved \\
\hline 27 & $\mathrm{Ni}$ & 90 & 50 & 75 & 71 & 61 & 70 & 72 & 70 & achieved & 61.3 & fail \\
\hline 28 & SU & 90 & 60 & 15 & 71 & 67 & 61 & 72 & 63 & remedial & 68.8 & achieved \\
\hline 29 & $\mathrm{UH}$ & 90 & 75 & 85 & 86 & 56 & 78 & 73 & 77 & achieved & 75.0 & achieved \\
\hline 30 & VMS & 67 & 70 & 75 & 86 & 56 & 71 & 72 & 71 & achieved & 78.8 & achieved \\
\hline 31 & WS & 67 & 50 & 65 & 71 & 56 & 62 & 70 & 63 & remedial & 71.3 & achieved \\
\hline 32 & $\mathrm{Yd}$ & 62 & 75 & 70 & 57 & 78 & 68 & 70 & 69 & achieved & 58.8 & fail \\
\hline 33 & YHA & 90 & 90 & 100 & 93 & 83 & 91 & 80 & 89 & achieved & 72.5 & achieved \\
\hline 34 & YEP & 90 & 60 & 60 & 86 & 83 & 76 & 80 & 77 & achieved & 76.3 & achieved \\
\hline \multicolumn{2}{|c|}{ Mean Score } & 79.5 & 62.2 & 58.6 & 75.2 & 67.6 & 68.6 & & 69.3 & & 72.1 & \\
\hline \multicolumn{2}{|c|}{ total achieved } & 26 & 13 & 19 & 27 & 17 & 23 & & 23 & & 31 & 31 \\
\hline \multicolumn{2}{|c|}{ total not achieved } & 0 & 9 & 12 & 1 & 9 & 6 & & 4 & & 1 & \\
\hline \multicolumn{2}{|c|}{$\%$ achieved } & 76 & 38 & 56 & 79 & 50 & 68 & & 68 & & 91 & 91 \\
\hline \multicolumn{2}{|c|}{$\%$ not achieved } & 0 & 26 & 35 & 3 & 26 & 18 & & 12 & & 3 & \\
\hline
\end{tabular}

Table 6 Students' Scores during Learning Activities and Reading Test in Cycle 2

\begin{tabular}{|r|l|r|r|r|r|r|l|r|l|}
\hline No & Name & exc 1 & exc 2 & ave & $\begin{array}{r}\text { ER } \\
\text { task }\end{array}$ & $\begin{array}{r}\text { Final } \\
\text { Score }\end{array}$ & note & $\begin{array}{r}\text { Reading } \\
\text { Test }\end{array}$ & note \\
\hline 1 & AS & 62 & 79 & 71 & 72 & 71 & achieved & 66.0 & achieved \\
\hline 2 & AN & 69 & 76 & 72 & 72 & 72 & achieved & 85.8 & achieved \\
\hline 3 & AB & 59 & 73 & 66 & 71 & 67 & achieved & 79.2 & achieved \\
\hline 4 & AD & 73 & 76 & 74 & 73 & 74 & achieved & 79.2 & achieved \\
\hline 5 & AF & 69 & 69 & 69 & 69 & 69 & achieved & 72.6 & achieved \\
\hline 6 & AH & 66 & 72 & 69 & 70 & 69 & achieved & 66.0 & achieved \\
\hline 7 & AM & 63 & 79 & 71 & 72 & 71 & achieved & 66.0 & achieved \\
\hline 8 & Anw & 73 & 65 & 69 & 73 & 70 & achieved & 79.2 & achieved \\
\hline
\end{tabular}


REGISTER JOURNAL

Vol. 11, No. 2, 2018, pp.121-138 p-ISSN: 1979-8903; e-ISSN : 2503-040X Website: http://journalregister.iainsalatiga.ac.id/index.php/register/ DOI : http://dx.doi.org/10.18326/rgt.v11i2.168-191

\begin{tabular}{|c|c|c|c|c|c|c|c|c|c|}
\hline 9 & $\mathrm{AR}$ & 73 & 76 & 74 & 73 & 74 & achieved & 72.6 & achieved \\
\hline 10 & AYF & 76 & 76 & 76 & 72 & 75 & achieved & 79.2 & achieved \\
\hline 11 & AMA & 66 & 76 & 71 & 74 & 72 & achieved & 66.0 & achieved \\
\hline 12 & $\mathrm{AA}$ & 83 & 90 & 86 & 75 & 83 & achieved & 79.2 & achieved \\
\hline 13 & Dn & 73 & 73 & 73 & 73 & 73 & achieved & 66.0 & achieved \\
\hline 14 & $\mathrm{DC}$ & 90 & 100 & 95 & 80 & 90 & achieved & 92.4 & achieved \\
\hline 15 & $\mathrm{AQF}$ & 86 & 93 & 90 & 76 & 86 & achieved & 59.4 & fail \\
\hline 16 & EA & 73 & 68 & 70 & 72 & 71 & achieved & 72.6 & achieved \\
\hline 17 & EW & 73 & 86 & 79 & 74 & 78 & achieved & 66.0 & achieved \\
\hline 18 & ETJ & 76 & 78 & 77 & 73 & 76 & achieved & 85.8 & achieved \\
\hline 19 & IY & 66 & 76 & 71 & 72 & 71 & achieved & 66.0 & achieved \\
\hline 20 & IP & 62 & 73 & 67 & 72 & 69 & achieved & 72.6 & achieved \\
\hline 21 & $\mathrm{JH}$ & 65 & 66 & 65 & 73 & 68 & achieved & 85.8 & achieved \\
\hline 22 & JP & 80 & 85 & 82 & 79 & 81 & achieved & 92.4 & achieved \\
\hline 23 & $\mathrm{MZ}$ & 72 & 96 & 84 & 74 & 81 & achieved & 79.2 & achieved \\
\hline 24 & MK & 76 & 89 & 82 & 76 & 80 & achieved & 85.8 & achieved \\
\hline 25 & $\mathrm{Nd}$ & 86 & 83 & 84 & 79 & 83 & achieved & 72.6 & achieved \\
\hline 26 & NS & 65 & 68 & 67 & 74 & 69 & achieved & 79.2 & achieved \\
\hline 27 & $\mathrm{Ni}$ & 69 & 62 & 65 & 74 & 68 & achieved & 59.4 & fail \\
\hline 28 & SU & 51 & 65 & 58 & 74 & 63 & remedial & 72.6 & achieved \\
\hline 29 & $\mathrm{UH}$ & 76 & 83 & 79 & 76 & 78 & achieved & 85.8 & achieved \\
\hline 30 & VMS & 73 & 89 & 81 & 74 & 79 & achieved & 72.6 & achieved \\
\hline 31 & WS & 66 & 71 & 68 & 72 & 69 & achieved & 72.6 & achieved \\
\hline 32 & Yd & 76 & 75 & 75 & 72 & 74 & achieved & 66.0 & achieved \\
\hline 33 & YHA & 100 & 100 & 100 & 80 & 94 & achieved & 85.8 & achieved \\
\hline 34 & YEP & 86 & 87 & 86 & 79 & 84 & achieved & 92.4 & achieved \\
\hline \multicolumn{2}{|c|}{ Average } & 72.6 & 78.5 & 75.6 & & 75.1 & & 75.7 & \\
\hline \multicolumn{2}{|c|}{ total achieved } & 28 & 33 & 33 & & 33 & & 32 & \\
\hline \multicolumn{2}{|c|}{ total not achieved } & 6 & 1 & 1 & & 1 & & 2 & \\
\hline \multicolumn{2}{|c|}{$\%$ achieved } & 82 & 97 & 97 & & 97 & & 94 & \\
\hline \multicolumn{2}{|c|}{$\%$ not achieved } & 18 & 3 & 3 & & 3 & & 6 & \\
\hline
\end{tabular}

There were any other factors that influence the students learning. The implementation of Number Heads Together in grouping system had a positive and negative impact. Active students who were familiar with the computer and the Internet did not face a problem whenever they got different group mate each meeting, meant that they were able to socialize with everyone in the class. In contrast, those who were dependent on friends to help learning got the problem in adaptation when they had to work with others. The two students who failed in the reading comprehension test and one who failed in the on-going performance needed a remedial course to improve their comprehension. 


\section{DISCUSSION}

Online Short Stories is a kind of reading materials presented on the Internet which can be utilized both online and offline, indeed, online reading is more interesting. The choice of OSS as a learning strategy is under the reason of its multifunction, as a medium and materials, as Tyner and Green (2005) state that strategy can be any kind of tools that a teacher uses to help students learn. In addition, teaching and learning procedure in English lesson can be done by using Internet materials because Internet media has entered schools faster than books (Leu, 2002 cited in Anderson, 2003). It is in line with the implementation of Computer Based Instruction (CBI) in which the students get a wide exposure to interact with many kinds of texts in which graphics, pictures even sounds are presented within its authenticity ( $\mathrm{Li} \&$ Hart, 2002). The natural presentation can be seen in the features design and language used in the range of readers or viewers levels, topics or subjects being explored, and interests.

The appropriateness of the OSS for the eighth graders is that the texts presented in the form of narrative and descriptive which match to the curriculum. The length of the texts varies. All texts come with pictures or animation and audio supports in the colorful and interesting face. Although these materials are labeled for kids as the word "kids" put down in the web page, these are suitable for the teenagers who are in the early reader stage because English is learned as a foreign language in Indonesia. The students in this stage need to interact with the picture or animation to understand the meaning of the text (Ellery, 2005).

In the implementation of OSS in the eighth-grade students of Islamic, Junior High School have attracted their curiosity to explore the web that comprises those materials. The difficulty of remembering and typing the web address was the problem that the students faced in the first and second time they interact with the Internet. That was overcome by saving the address in Bookmark. This is one of the approaches that are proposed by Burkhart and Kelly (1999 cited in Male, 2003) in utilizing the Internet after selecting and previewing appropriate websites. Some others are setting clear objectives, deciding experiences in large groups, individual or combination of both, preparing graphic organizer, rubric, or a set of directions, and planning the way of assessing. The students who were fond of online games have also been familiar with English terms generally used in that feature. Their knowledge on the computer and Internet terms helped them to start and work with. 
OSS was not the sole device that was used for intensive and extensive reading activities. Five worksheets were designed in order to use the OSS effectively focused on comprehension. They are Self Monitoring Card, Key Concept, Story Map, Reading Journal, and Reading Log. The two worksheets were utilized in whilst reading to ensure the students catch the core of the text. Then, story map was employed in post-reading phase to assist them in maintaining their understanding. However, in the middle of the study, the researcher created some quizzes that were adapted from the OSS activity. This was to relieve the students' boredom in facing the same form of the worksheet that seemed they were driven to understand the materials instantly. Reading Journal and Log were the main devices for extensive reading. All were constructed in the regard that comprehension must be taught through systematic instruction (Tyner \& Green, 2005) in order to engage them with the meaning of the text and lead them to apply their own strategies (Ur, 1996).

Because the OSS presented with the images, some students chose their readers based on the picture they thought was more interesting. This could be concluded that the effect of the features on the motivation was good. Hence, through the animation, they could follow the plot of the story in sequence and understand the events happened easier. The main problem was that they could say something about the story, of course in Indonesian, but they did not have any idea to write down the answer to the questions in the worksheet. The worksheets were then functioned as the means to recall the information and copy the important thing from the text, especially dealing with the basic $5 \mathrm{~W}+\mathrm{H}$ questions and the series of events. These two tools were interrelated to the treatment for determining the main idea of the text and finding detail information. The last, Story Map worksheet was used as a way to make a summary which applied in the reading journal enclosed in the extensive reading record.

Dealing with the reading strategies that the students applied, the result of the students' self-assessment on the strategies applied in online reading, after the treatment within six meetings proved an improvement on their awareness to be good readers who employ some important strategies. Those include establishing reading purpose, determining the main idea, organizing information, and monitoring their comprehension (O’Malley \& Pierce, 1996). The change in students' reading strategies illustrated that every student might use one that was suitable for their reading. This was so as the reading strategies used in printed and hypertext materials were the same. They were different on the frequency. 
The finding on the late submission of extensive reading record book was caused by the researcher's less consideration of the students' needs, especially on fairness-scoring, and facilities provided. The finding on extensive reading was far from the expectation as being recommended by Busthomi (2009) that the students were asked to read at least two texts a week with the teacher's guidance and support in terms of reading materials and explanation. However, the result of this study sounded good because there has never been an extensive reading practice before in the subject class, even the school. Then, in the implementation, the researcher did not purely let the students accomplish their reading out of the classroom by themselves, in spite of providing her time to stay in a computer room and providing any help for whom needed her. Thus, this study facilitated the students in terms of access because the materials used were taken from the Internet.

The implementation of cooperative learning in this study, mainly Number Head Together, decreased the students' tendency to be choosy in the grouping. It has also positive effects not only on students' achievement but also on other important factors such as motivation, social skills (including relationship skills and acceptance of diversity level of ability) and fond of learning at school.

The overall result of the students' reading achievement from the first to the third test and daily scores indicated that the implementation of OSS in pairing or grouping encouraged the students' involvement. This kind of cooperative learning provides an opportunity for the students to share their responsibility for the task given. Positive interdependence is raised from individual accountability to help and encourage each other so that the all members finish the work assigned (Male, 2003). The OSS worksheets which consist of comprehension questions are the learning tools for grouping in which each member has a responsibility to help others understand different aspects of the given task. This task division helped students improved their comprehension that was proved by the mean score they achieved, from 51.1 in the preliminary test, 72.1 in the comprehension test of Cycle 1, and 75.7 in Cycle 2.

In short, the success of the implementation of OSS with the companion of some worksheets enhanced the students' motivation and involvement in terms of grouping and giving comments during classroom discussion. This was also confirmed by the students' achievement during the learning activities in which they gained slightly improvement from the beginning to the end. The significant progress could be seen from the comparison on the test achievement before and after the treatment. The findings that the score of some students 
decreased might be influenced by the students' internal factor such as the condition of healthiness or motivation. Therefore, the teacher's role was essential for the success of the implementation of the strategy, not only as a facilitator who trained the comprehension strategy but also as a friend to whom the students could ask for learning guidance both inside and outside the classroom.

\section{CONCLUSION}

The results of the study show that the use of Online Short Stories can improve the students' reading comprehension of the eighth graders of MTs Al-Islam Joresan Mlarak Ponorogo. Online Short Stories here play its role as medium and materials that provide students a lot of narrative texts with animations and oral reading and some quizzes. This strategy also enhances the students' learning in terms of motivation and interest as well as their way to implement reading strategy for online texts. The results show that the students' involvement during the teaching and learning process are gradually fostered as they experienced to work with the texts they chose freely. The implementation of cooperative learning that is combined with the use of Online Short Stories help them much in coping with their problem in reading as well as in collaborating. However, a small number of the students who had not achieved the minimum passing criteria needed to get the remedial course. These two students were not contented to work with some other friends through random grouping because of their dependence on their close friends. In brief, this study suggests that it is important to integrate Internet resources in the teaching of English in order to create a more interesting and effective teaching.

\section{REFERENCES}

Anderson, M., \& Anderson, K. (1998). Text Types in English 3. South Yarra: Macmillan Education.

Anderson, N. J. (2003). Scrolling, Clicking, and Reading English: Online Reading Strategies in a Second/Foreign Language. The Reading Matrix: An International Journal, 3:3. (Online). (www.readingmatrix.com), accessed on November 26, 2010. 
Argarini, D. (2008). Improving Students' Reading Comprehension through Intensive and Extensive Reading Activity at MTsN 3 Surabaya. (Unpublished thesis). Malang: Universitas Negeri Malang.

Atmadja, W. (February 27, 2009). "Smart house" to Encourage Reading Habit among Students. Jakarta Post. (Online), (www.thejakartapost.com), accessed on 10 March 2010.

British Council. (Online). http://www.learnenglishkid.britishcouncil.org/short-stories.

Busthomi, N. R. (2009). The Effectiveness of Extensive Reading Activity in Increasing Reading Comprehension and Reading Speed of English Texts of Ninth Grade Students of MTsN Negeri 1 Pamekasan. (Unpublished thesis). Malang: Universitas Negeri Malang.

Depdiknas. (2006). Peraturan Menteri Pendidikan Nasional no 23 tahun 2006 tentang Standar Kompetensi Lulusan untuk Satuan Penidikan Dasar dan Menengah. Jakarta: Depdiknas.

Effendy, H. (2005). Developing Multimedia CD-Rom Courseware to Elevate Students' Vocabulary Mastery in Senior High School. (Unpublished Thesis). Malang: Universitas Negeri Malang.

Ellery, V. (2005). Creating Strategic Readers. Newark: IRA.

Harmer, J. (2007). The Practice of English Language Teaching. Harlow: Pearson Education.

Hopkins, D. (2008). A Teacher's Guide to Classroom Research. New York: Open University Press.

Kemmis, S., \& McTaggart, R. (1988). The Action research Planner. Gee Long: Deakin University Press.

Khamim. N. (2009). The Effect of Multimedia to Assist The Teaching of Descriptive Paragraph Writing at SMPN 37 Semarang. (Unpublished Thesis). Malang: Universitas Negeri Malang.

Klingner, J. K., Vaughn, S., \& Boardman, A. (2007). Teaching Reading Comprehension to Students with Learning Difficulties. New York: The Guilford Press.

Li, R.C., \& Hart, R.S. (2002). What Can the World Wide Web Offer ASL Teachers? In J. C. Richards, \& W. A. Renandya, (Eds). Methodology in Language Teaching: An Anthology of Current Practice (pp.295-302). Cambridge: Cambridge University Press. 
Male, M. (2003).technology for Inclusion: Meeting the Special Needs of All Students. Boston: Pearson Education.

McKnight, K. S. (2010). The Teacher's Big Book of Graphic Organizers. San Francisco: Jossey-Bass.

Mikulecky, L. J. Using Internet-Based Children's Literature to Teach EFL. The Internet TESL Journal 13 (11), November 2007, (Online), (http://iteslj.org/), accessed on February 7, 2010.

Mochtar, T. M. T., \& Saad, M. R. M. Enhancing Reading through the Internet. In Muhammad K. K. \& Malachi, E. V. (2007). Internet and the English Language Classroom. Petaling Jaya: Sasbadi. Sdn. Bhd.

Neyman, P. F. (2002). Helping Children Learn to Think in English Through Reading Storybooks. Internet TESL Journal 3 (8), August 2002. (Online), (http://iteslj.org/), accessed on February 7, 2009.

Nuttal, C. (1982). Teaching Reading Skills in a Foreign Language. London: Heinemann Educational Books.

O’Malley, J. M., \& Pierce, L. V. (1996). Authentic Assessment for English Language Learners: Practical Approaches for Teachers. White Plains, NY: Addison Wesley.

Renandya, W. A., \& Jacobs, G. M. (2002). Extensive Reading: Why Aren't We All Doing It?. In J. C. Richards, \& W. A. Renandya, (Eds). Methodology in Language Teaching: An Anthology of Current Practice (pp.295-302). Cambridge: Cambridge University Press.

Richards, J. C., \& Rodgers, T. S. (2001). Approaches and Methods in Language Teaching (2 $2^{\text {nd }}$ ed). Cambridge: Cambridge University Press.

Rong-Chang. (2010). (Online). http://www.rong-chang.com/qa2

Silva, J. P. (2006). Extensive Reading through the Internet: Is It worth The While?. (Online), (http://www.readingmatrix.com/articles/silva/article.pdf), retrieved on February 2, 2010.

Tyner, B., \& Green, S. (2005). Small Group Reading Instruction: A Differentiated Teaching Model for Intermediate Readers, Grades 3-8. Newark: IRA.

Ur, P. (1996). A Course in Language Teaching. Cambridge: Cambridge University Press.

Vacca, R, T., \& Vacca, J. A.L. (1999). Content Area Reading: Literacy and Learning across Curriculum. $\left(6^{\text {th }} \mathrm{ed}\right)$. New York: Addison-Wesley. 
Muhammad Lukman Syafi 